\title{
The study of copy number variations in the regions of PRKAB2 and PPM1K among congenital heart defects patients
}

1. Department of Pneumology, Tianjin Children's Hospital, Tianjin, 300074-China 2. Department of Child Healthcare, Tianjin Municipal Women and Children health care center, Tianjin, 300070 , China

\section{SUMMARY}

OBJECTIVE: This study was to assess the genetic association of copy number variations in two genes (PRKAB2 and PPM1K) located in two regions (tetralogy of Fallot and ventricular septal defect) in a Chinese Han population.

METHODS: A total of 200 congenital heart disease patients (100 tetralogy of Fallot patients and 100 ventricular septal defect patients) and 100 congenital heart defect-free controls were recruited, and quantitative real-time PCR analysis was used to replicate the association of two copy number variations with congenital heart defects in a Chinese Han population.

RESULTS: One deletion at PRKAB2 and one duplication at PPM1K were found in two of the tetralogy of Fallot patients, respectively; while all these regions were duplicated in both ventricular septal defect patients and in the 100 congenital heart defects-free controls.

CONCLUSIONS: We replicated the copy number variations at the disease-candidate genes of PRKAB2 and PPM1K with tetralogy of Fallot in a Chinese Han population, and in patients with ventricular septal defect mutations in these two genes were not found. These results indicate the same molecular population genetics exist in these two genes with different ethnicity. This shows that these two genes are possibly specific pf tetralogy of Fallot candidates.

KEYWORDS: Tetralogy of Fallot. Heart Septal Defects, Ventricular. Genetic Variation. Chromosome Mapping.

\section{INTRODUCTION}

There are many forms of variation included in the human genome. In 2006, copy number variations were defined for a series of discoveries previously made as a DNA segment of $1 \mathrm{~kb}$ or larger, which presented variable copy numbers, in comparison with a reference genome. ${ }^{1}$ Copy number variations have been reported to influence gene expression by altering gene dosage and through the effect of its position. ${ }^{2}$ Several diseases have been shown to be caused by the duplication of specific genes. Hence, in this study, we analyzed the copy number variations of genes PRKAB2 and PPM1K within ventricular septal defect and tetralogy of Fallot patients.

Ventricular septal defect is the $2^{\text {nd }}$ most common type of congenital heart defect (32\%) and characterized as a defect in the septum between the right and left ventricle; while the tetralogy of Fallot is relatively rare, and is defined as the combination of a mispositioned aorta that overrides both ventricles, ventricular septal defect, pulmonary stenosis, and right ven- 
tricular hypertrophy. Both congenital heart defects, ventricular septal defect and tetralogy of Fallot have a prevalence of $0.16 \%$ and $0.05 \%$ in births, respectively.,4 AMP-activated protein kinase, a central cellular energy regulator, has recently emerged as a primary candidate for its role in metabolic dysfunction. ${ }^{5}$ The amp-activated protein kinase is highly conserved and consists of a $\alpha$-catalytic subunit and $\beta$ and $\gamma$ regulatory subunits. PRKAB2 (AMPKB2), the gene that encodes the $\beta 2$ regulatory subunit, is located in 1q21.2. Northern blot analysis revealed that AMP-activated protein kinase-beta-2 is expressed as a 7.5-kb mRNA in a variety of human tissues, with the highest levels in skeletal and cardiac muscles. ${ }^{6}$ Studies of AMP-activated protein kinase in correlation with type-2 diabetes have been the main research focus, concerning PRKAB2. ${ }^{7}$ Another newly discovered gene, PPM1K (also called PP2Cm) (a mitochondrial matrix-targeted protein phosphatase $2 \mathrm{C}$ family member), demonstrated that it was essential for cell survival and healthy development and that it was highly conserved among vertebrates, with the highest expression levels detected in the heart and brain. As a new member of the Ser/Thr protein phosphatase from the PP2C family, the gene encodes a 372-amino-acid protein. The knockdown of PP2Cm resulted in cell death associated with loss of mitochondrial membrane potential in cultured cardiac myocytes and induction of hepatocyte apoptosis in vivo. ${ }^{8}$

We hypothesize copy number variations that cover the region of PRKAB2 and PPM1K alter the dosage of genes involved in cardiac development and account for the isolated tetralogy of Fallot. In addition, we seek to unravel the problem of whether both copy number variations are relevant, particularly with tetralogy of Fallot. Hence, we performed replication experiments in Chinese ventricular septal defect patients. Both gene PRKAB2 and PPM1K were selected in this study, according to the previous report of de novo copy number variations ${ }^{9}$, to perform this replication in Chinese tetralogy of Fallot and ventricular septal defect patients.

\section{METHODS}

\section{Study subjects}

A total of 200 nonsyndromic congenital heart defect patients (100 tetralogy of Fallot patients and 100 ventricular septal defect patients) and 100 congenital heart defect-free controls were recruited from Tian- jin Children's hospital into this study. Informed consent was obtained from their parents or guardians. This study protocol conforms to the ethical guidelines of the 1975 Declaration of Helsinki.

The clinical assessment performed in patients included anthropometric measurement, physical examination for dysmorphism and malformation, and radiological evaluation. These patients also underwent chest X-ray examination, electrocardiogram, and ultrasonic echocardiogram.

\section{Quantitative Real-Time PCR Analysis}

Blood samples from congenital heart defect patients and controls were collected and stored at $-20^{\circ} \mathrm{C}$. Genomic DNA was extracted from peripheral blood leukocytes using standard methods (QIAamp DNA Mini Kit, Qiagen, Hilden, Germany).

The exon regions of the PRKAB2 and PPM1K genes were used for real-time primer design. The primer sequences of these candidate genes were designed on the basis of the sequence data obtained from the NCBI database (http://www.ncbi.nlm.nih/org), using Primer Express software 3.0 (Applied Biosystems) (Table 1).

Those regions were amplified in all 200 patients and 100 congenital heart defect-free control individuals using real-time quantitative polymerase chain reaction (qPCR) with a set of gene-specific primers. ${ }^{10}$

The gDNA was used as a template in real-time qPCR reactions with SYBR $^{\circledR}$ Green PCR Master Mix (Takara Biotechnology [Dalian] Co. Ltd.), which was performed using a 7000 real-time PCR system (Applied Biosystems, USA). ${ }^{11,12}$ The quantification of these target sequences was normalized to an assay from chromosome 21, C2, and the relative copy number (RCN) was determined on the basis of the comparative $\Delta \Delta \mathrm{Ct}$ method, with a normal control DNA as the calibrator. These experiments were repeated three times. An approximately 0.5-fold RCN and approximately 1.5-fold RCN were used for deletion and duplication, respectively.

TABLE 1. LIST OF Q-REAL-TIME-PCR PRIMERS

\begin{tabular}{|l|l|}
\hline $\begin{array}{l}\text { Candidate } \\
\text { Gene-Primer ID }\end{array}$ & Primer sequence \\
\hline PRKAB2-F & 5'- GCCAAAGCTCACTGTTGTTGGTTA -3' \\
\hline PRKAB2-R & 5'- GACAGACACAGAGCTGCACTCATTC -3' \\
\hline PPM1K-F & 5'-GAGGAACCAAAGGGAGGCAACT -3' \\
\hline PPM1K-R & 5'- TCCTTTGCCTGTTGGTTTGGA -3' \\
\hline C2-F & 5'-CAATTCAGGTCAGGTGATAACTCAGTAA-3' \\
\hline C2-R & 5'-GCCAGGTTTAGAATGTTTGTCTAAGTC-3' \\
\hline
\end{tabular}




\section{RESULTS}

\section{Real-Time quantitative PCR analysis}

The present study included 100 ventricular septal defects and 100 tetralogy of Fallot patients. In order to aim directly at each gene region, specific primers were designed in the exon regions of those genes, in which the amplification segment of the PRKAB2 gene was at the $8^{\text {th }}$ exon, while that of the PPM1K gene was at the $7^{\text {th }}$ exon. Both segments were in the 3'UTR regions.

PRKAB2, located at 1q21.1, which has been previously implicated in congenital heart defects ${ }^{13}$, has been found to have copy number variations in the same region in the present study. According to the Greenway et al. ${ }^{9}$ study, there were four duplications and one deletion in five subjects with tetralogy of Fallot, and the shared segment spans a small interval on chromosome 1q21.1. The present study found a deletion at the $8^{\text {th }}$ exon of the PRKAB2 gene in one tetralogy of Fallot patient, while no duplication or deletion was found in all ventricular septal defect patients (Figure 1a).

Copy number variations at $4 q 22.1$ in tetralogy of Fallot patients have been reported in a previous study ${ }^{9}$, and the region is where the PPM1K gene located. Combined with the results of our experiment, a correlation between tetralogy of Fallot and the PPM1K gene is strongly suggested. Meanwhile, all patients with ventricular septal defects were duplicated in the same region of this gene (Figure 1b).

In order to confirm the copy number variations found in the present study, real-time qPCR was performed at least three times to get rid of human-made handling errors.
As expected, there were no deletions or duplications detected in all 100 congenital heart defect-free controls according to the qPCR result.

\section{DISCUSSION}

At the $1 \mathrm{q} 21.1$ region, according to real-time qPCR results, deletions were found at the PRKAB2 gene region in one tetralogy of Fallot patient. Since more recent copy number variations at this locus were identified in subjects with neurocognitive, psychiatric, and developmental phenotypes, ${ }^{14-20}$ we confirm that tetralogy of Fallot subjects with 1q21.1 copy number variation identified in the present study had normal cognition, social behavior, and neurologic function.

AMPKbeta2 in the N-terminal region may play a role in isoform-specific AMP-activated protein kinase activity, ${ }^{6}$ and it was proven that AMPKB2 was highly expressed in the skeletal muscle, with low expression in the liver. AMP-activated protein kinase beta subunit contains a functional glycogen binding domain, and the mutation of glycogen binding residues may completely abolish beta-GBD binding to glycogen.21 This suggests that this gene is associated with diabetes. AMPKbeta2 was also expressed in the heart, along with its other subunits. However, no disease-causing mutations were found in PRKAB2 in inherited cardiomyopathies. In another study, AMPKbeta2 was shown to be regulated by the p53 protein, which may be signaled to reduce the fidelity of cell growth and division, and responds by initiating cell cycle arrest, senescence, or apoptosis. ${ }^{22}$

Several SNPs at the $4 \mathrm{q} 22.1$ region have been reported and associated with bone mineral density (hip

FIGURE 1 DELETION AND DUPLICATION OF COPY NUMBER VARIATIONS SHOWN IN GENES PRKAB2 AND PPM1K IN TETRALOGY OF FALLOT PATIENTS, RESPECTIVELY.

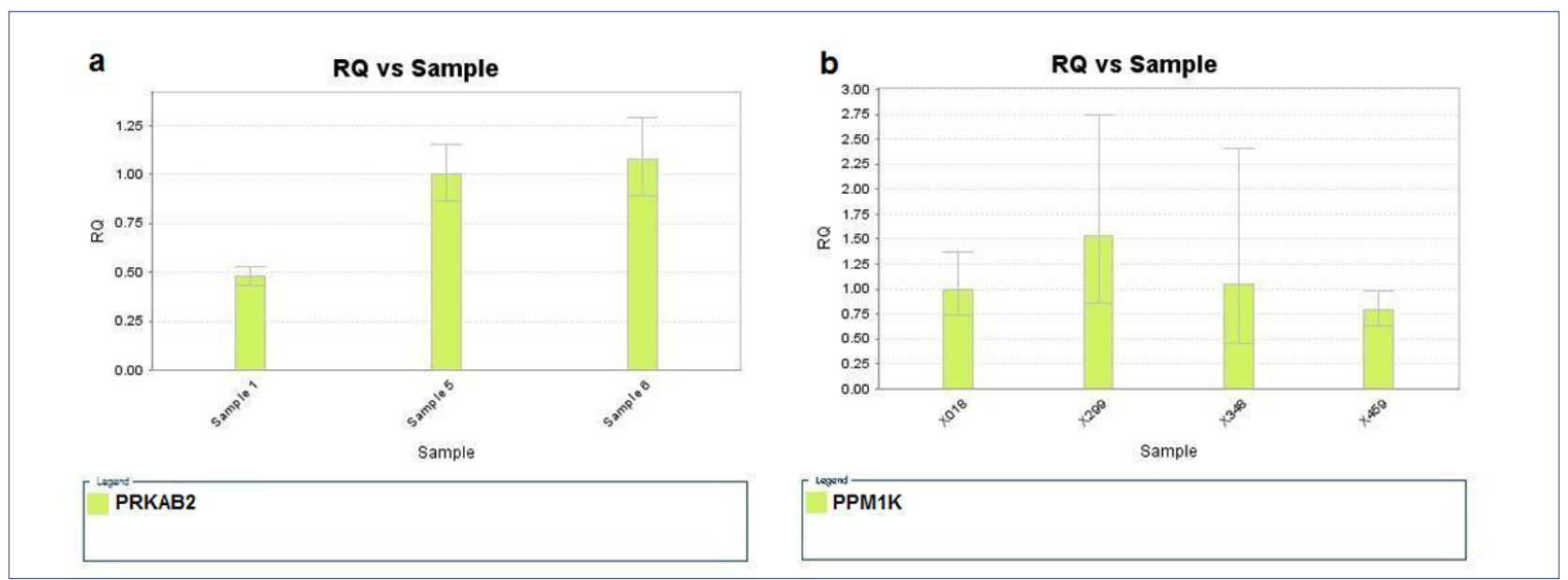


and spine) (MEPE), serum uric acid, serum urate (ABCG2) and conduct disorder (interaction) (PPM1K). ${ }^{23-25}$ However, there were no other previously reported studies on disease-candidate copy number variations in this region, except for the study of Greenway et al. ${ }^{9}$.

PPM1K is a mitochondrial protein phosphatase that plays an important role in normal development and cell survival and was discovered to specifically bind the branched-chain-alpha-ketoacid dehydrogenase (BCKD) complex and induce the dephosphorylation of Ser293 in the presence of BCKD substrates. PPM1K inactivation in developing zebrafish embryos caused abnormal cardiac, neural development, as well as heart failure. ${ }^{8}$ PPM1K-deficient mice exhibited catabolic defects similar to human maple syrup urine disease. ${ }^{26}$

Previous studies have discovered that copy number variation research has focused on neurological diseases such as Parkinson's and Alzheimer. ${ }^{27,28}$ In recent years, copy number variations were found to be more related with congenital disabilities. ${ }^{29,30}$ As one of the most common types of congenital disability, the pathological mechanism of congenital heart defects has also been said to be associated with copy number variations.

The less severe subtype ventricular septal defect is mainly due to the defect in the ventricular septum, which consists of the inferior muscular and superior membranous portion, while the ventricular septum is extensively innervated with conducting cardiomyocytes. In contrast, the tetralogy of Fallot involves four heart malformations presented together, which are pulmonary stenosis, overriding aorta, ventricular septal defect, and right ventricular hypertrophy. The first condition includes the narrowing of the right ventricular outflow tract, in which the PRKAB2 gene was found to be significantly expressed. This may be the explanation for why copy number variations that overlap the PRKAB2 region were not found in the ventricular septal defect, but only found in tetralogy of Fallot patients.

In conclusion, we replicated the disease-associated genes of PRKAB2 and PPM1K with tetralogy of Fallot in a Chinese Han population and verified that there was no correlation between those two genes and ventricular septal defect. These results indicate the same molecular population genetics in these two genes of different ethnicity. This shows that these two genes may be specific of tetralogy of Fallot candidates.

\section{Competing interests:}

The authors declare that they have no competing interests. There are no financial or other relationships to be declared.

\section{RESUMO}

OBJETIVO: Este estudo teve como objetivo avaliar a associação genética do número de cópias em dois genes (PRKAB2 e PPM1K) localizados em duas regiões (tetralogia de Fallot e comunicação interventricular) em uma população chinesa da etnia Han.

METOdologia: Um total de 200 pacientes com doença cardíaca congênita (100 pacientes com tetralogia de Fallot e 100 com comunicação interventricular) e 100 indivíduos livres de defeitos cardíacos congênitos foram recrutados, e uma análise quantitativa de PCR em tempo real foi utilizada para replicar a associação de duas variações de número de cópia de defeitos cardíacos congênitos, em uma população chinesa da etnia Han.

RESULTADOS: Uma supressão em PRKAB2 e duplicação em PPM1K foram encontradas em dois pacientes com tetralogia de Fallot, respectivamente; todas essas regiões estavam duplicadas nos pacientes com comunicação interventricular e nos 100 indivíduos livres de defeitos cardíacos congênitos.

CONCLUSÃO: Nós replicado a variações no número de cópias de genes candidatos de doença PRKAB2 e PPM1K com tetralogia de Fallot em uma população chinesa da etnia Han; em pacientes com comunicação interventricular, não foram encontradas mutações nesses dois genes. Estes resultados indicam que a mesma genética de população molecular existe nestes dois genes em diferentes etnias. Isso mostra que esses dois genes são possivelmente candidatos a genes específicos de tetralogia de Fallot.

PALAVRAS-ChaVE: Tetralogia de Fallot. Defeitos do septo, ventricular. Variação genética. Mapeamento cromossômico.

\section{REFERENCES}

1. Feuk L, Carson AR, Scherer SW. Structural variation in the human genome. Nat Rev Genet. 2006;7(2):85-97.

2. Redon R, Ishikawa S, Fitch KR, Feuk L, Perry GH, Andrews TD, et al. Global variation in copy number in the human genome. Nature. 2006;444(7118):444-54.
3. Ferencz C, Rubin JD, McCarter RJ, Brenner JI, Neill CA, Perry LW, et al. Congenital heart disease: prevalence at livebirth. The Baltimore-Washington Infant Study. Am J Epidemiol. 1985;121(1):31-6.

4. Martin GR, Perry LW, Ferencz C. Increased prevalence of ventricular septal defect: epidemic or improved diagnosis. Pediatrics. 1989;83(2):200-3. 
5. Hardie DG. Minireview: the AMP-activated protein kinase cascade: the key sensor of cellular energy status. Endocrinology. 2003;144(12):517983 .

6. Thornton C, Snowden MA, Carling D. Identification of a novel AMP-activated protein kinase beta subunit isoform that is highly expressed in skeletal muscle. J Biol Chem. 1998;273(20):12443-50.

7. Sun MW, Lee JY, Bakker PI, Burtt NP, Almgren P, Rastam L, et al. Haplotype structures and large-scale association testing of the 5' AMP-activated protein kinase genes PRKAA2, PRKAB1, and PRKAB2 [corrected] with type 2 diabetes. Diabetes. 2006;55(3):849-55.

8. Lu G, Ren SP, Korge P, Choi J, Dong Y, Weiss J, et al. A novel mitochondrial matrix serine/threonine protein phosphatase regulates the mitochondria permeability transition pore and is essential for cellular survival and development. Genes Dev. 2007;21(7):784-96.

9. Greenway SC, Pereira AC, Lin JC, DePalma SR, Israel SJ, Mesquita $S M$, et al. De novo copy number variants identify new genes and loci in isolated sporadic tetralogy of Fallot. Nat Genet. 2009;41(8):931-5.

10. Larionov A, Krause A, Miller W. A standard curve based method for relative real time PCR data processing. BMC Bioinformatics. 2005;6:62.

11. De Medici D, Croci L, Delibato E, Di Pasquale S, Filetici E, Toti L. Evalua tion of DNA extraction methods for use in combination with SYBR green I real-time PCR to detect Salmonella enterica serotype enteritidis in poultry. Appl Environ Microbiol. 2003;69(6):3456-61.

12. Wong LY, Cao Y, Balachandran $P$, Zoder $P$, Furtado MR, Petrauskene OV, et al. Validation of the Applied Biosystems MicroSEQ real-time PCR system for detection of E. coli O157:H7 in food. J AOAC Int. 2012;95(5):1495-504

13. Christiansen J, Dyck JD, Elyas BG, Lilley M, Bamforth JS, Hicks M et al. Chromosome 1q21.1 contiguous gene deletion is associated with congenital heart disease. Circ Res. 2004;94(11):1429-35.

14. Xu B, Roos JL, Levy S, van Rensburg EJ, Gogos JA, Karayiorgou $M$. Strong association of de novo copy number mutations with sporadic schizophrenia. Nat Genet. 2008;40(7):880-5.

15. Stefansson H, Rujescu D, Cichon S, Pietiläinen OP, Ingason A, Steinberg S, et al. Large recurrent microdeletions associated with schizophrenia. Nature. 2008;455(7210):232-6.

16. Vries BB, Pfundt R, Leisink M, Koolen DA, Vissers LE, Janssen IM, et al. Diagnostic genome profiling in mental retardation. Am J Hum Genet. 2005;77(4):606-16

17. Brunetti-Pierri N, Berg JS, Scaglia F, Belmont J, Bacino CA, Sahoo $T$, et al. Recurrent reciprocal 1q21.1 deletions and duplications associated with microcephaly or macrocephaly and developmental and behavioral abnormalities. Nat Genet. 2008;40(12):1466-71.

18. Mefford HC, Sharp AJ, Baker C, Itsara A, Jiang Z, Buysse K, et al. Recurrent rearrangements of chromosome 1q21.1 and variable pediatric phenotypes. N Engl J Med. 2008;359(16):1685-99.
19. Walsh $T$, McClellan IM, McCarthy SE, Addington AM, Pierce SB, Cooper GM, et al. Rare structural variants disrupt multiple genes in neurodevelopmental pathways in schizophrenia. Science. 2008;320(5875):53943.

20. Sharp AJ, Hansen S, Selzer RR, Cheng Z, Regan R, Hurst JA, et al. Discovery of previously unidentified genomic disorders from the duplication architecture of the human genome. Nat Genet. 2006;38(9):1038-42.

21. Polekhina G, Gupta A, Michell BJ, van Denderen B, Murthy S, Feil SC, et al. AMPK beta subunit targets metabolic stress sensing to glycogen. Curr Biol. 2003;13(10):867-71.

22. Oliveira SM, Ehtisham I, Redwood CS, Ostman-Smith I, Blair EM, Watkins H. Mutation analysis of AMP-activated protein kinase subunits in inherited cardiomyopathies: implications for kinase function and disease pathogenesis. J Mol Cell Cardiol. 2003;35(10):1251-5.

23. Feng Z, Hu W, de Stanchina E, Teresky AK, Jin S, Lowe S, et al. The regulation of AMPK beta1, TSC2, and PTEN expression by p53: stress, cell and tissue specificity, and the role of these gene products in modulating the IGF-1-AKT-mTOR pathways. Cancer Res. 2007;67(7):3043-53.

24. Rivadeneira F, Styrkársdottir U, Estrada K, Halldórsson BV, Hsu YH, Richards |B, et al; Genetic Factors for Osteoporosis (GEFOS) Consortium. Twenty bone-mineral-density loci identified by largescale meta-analysis of genome-wide association studies. Nat Genet .2009;41(11):1199-206.

25. Sonuga-Barke EJ, Lasky-Su J, Neale BM, Oades R, Chen W, Franke $B$, et al. Does parental expressed emotion moderate genetic effects in ADHD? An exploration using a genome wide association scan. Am | Med Genet B Neuropsychiatr Genet. 2008;147B(8):1359-68.

26. Dehghan A, Köttgen A, Yang Q, Hwang SJ, Kao WL, Rivadeneira F, et al. Association of three genetic loci with uric acid concentration and risk of gout: a genome-wide association study. Lancet. 2008;372(9654):195361.

27. Lu G, Sun H, She P, Youn JY, Warburton S, Ping P, et al. Protein phosphatase $2 \mathrm{Cm}$ is a critical regulator of branched-chain amino acid catabolism in mice and cultured cells. J Clin Invest. 2009;119(6):1678-87.

28. Singleton AB, Farrer M, Johnson J, Singleton A, Hague S, Kachergus J, et al. alpha-Synuclein locus triplication causes Parkinson's disease. Science. 2003;302(5646):841.

29. Rovelet-Lecrux A, Hannequin D, Raux G, Le Meur N, Laquerrière A, Vital A, et al. APP locus duplication causes autosomal dominant early-onset Alzheimer disease with cerebral amyloid angiopathy. Nat Genet. 2006;38(1):24-6.

30. Stamm DS, Siegel DG, Mehltretter L, Connelly JJ, Trott A, Ellis N, et al; NTD Collaborative Group. Refinement of $2 q$ and $7 p$ loci in a large multiplex NTD family. Birth Defects Res A Clin Mol Teratol. 2008;82(6):441-52 